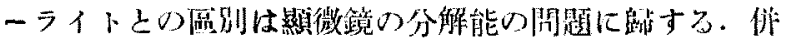

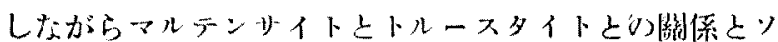

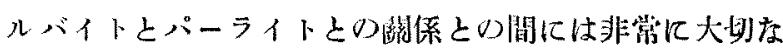
䛛别がある.マルテンサイトとトルースタイトとはPSK

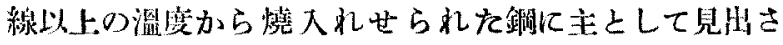
れ、ソルバイト上パーライトとはPSK 線潈度通過の冷

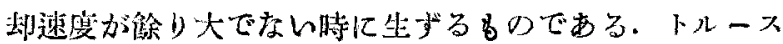

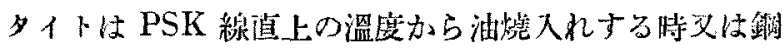

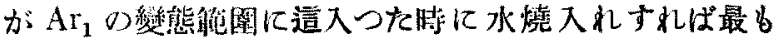

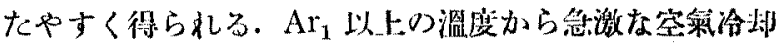
をすればソルバイトが得られ，てれよりも冷却速度が非

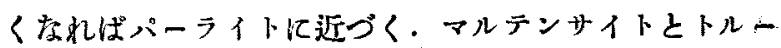
スタイトとが相維聯して現はれるやうに，ソルバィトと

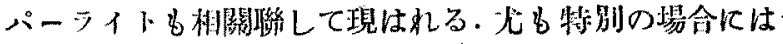
一つの壾料中にこの 4 種の組織が全部現はれるこをる ある。

\title{
球狀七ノンタイト(I) (輯錄)
}

\section{I. 緒 言}

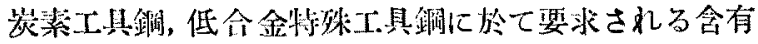
炭化物の非忦化作菜については，賽際作業の必要上，誚椣 の實驗研究が行はれてわる。

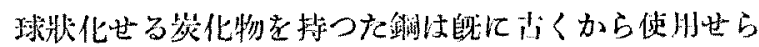
れをるので, N.T. Belaiew(1)によれば,がD Damascence steel b，球狀化せる炭化物葆持つてるるといふてとで ある.

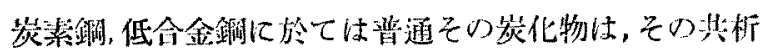
組成に於て，粗粒波 (sorbite)或心督状の波來上(pearlite) の形で現れるが，或る埸合には球狀をなつて現れる。 乙の場今の共析租战老球状波米上 (globular pearlite) 又は粒肤波桃土（granular pearlite）上稱し，球彇化せる 炭化物老，球彇七ヌンタイト (globular cementite or spheroidal cementite) 又は精诜七メンタイト (granular

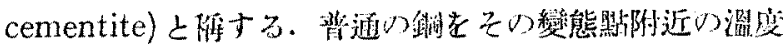

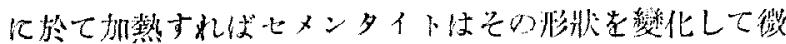

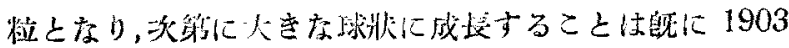

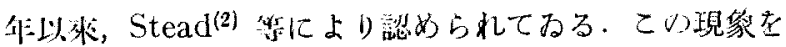
球状化 (spheroidization) 上齐方.

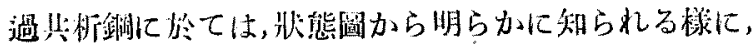
或る溫应に於て七メンタイトは $\gamma$ 相に間溶してしまふ。 が，その淄度から冾却すれば，Acm 點にてセメンタイト

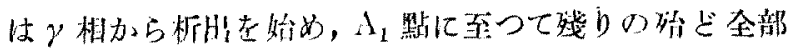

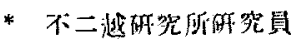

(1) N. T Belaisw, J. Iron \& Stec] [nst., 97 (1918), 419 ; $104(1921), 181$

(2) J. E. Stead, J. Soc. Chem. Ind, 22 (1903), 340; I H. Whitely, J. Iron \& Steel Inst., 105 (1922), 339 ; F. Körber, W. Töster, Nitt. K.-W.-I. Eisenforsch, $5(1924), 145$.

\section{近 藤 正 男*}

が析山する, Acm 點化て析出するセメンタイト(初析七 メンタイト)は $\gamma$ 相の結昆垃韭又はその辟開面に現れる 品， $A_{1}$ 點に於て析出するヒメンタイトは地鐵(Ferrite)と 间時に析出して結晶粒內に現れる。七メンタイトの球状 化の機棈を知るには，些づ Acm 點及び $A_{1}$ 點に於ける七

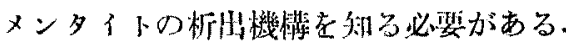

\section{II. $\gamma$ 相より球狀セメンタイトの析出}

\section{(1) 鐵の炭化物 ${ }^{(3)}$}

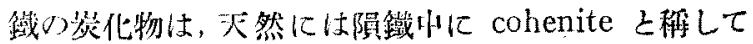
$(\mathrm{Fe}, \mathrm{Co}, \mathrm{Ni})_{3} \mathrm{C}$ の形で付在するが(4)，人工的には純鐵上炭

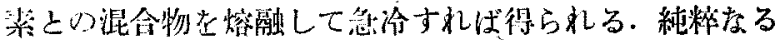

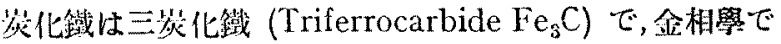
はヒメンタイト (cementite) と棹せられる。乙の組成は $6.67 \% \mathrm{C}, \quad 93.33 \% \mathrm{Fe}$

である.セメンタイトは䕀状の制れ易い絬晶で，比重は

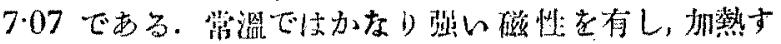

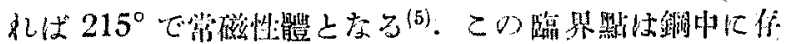

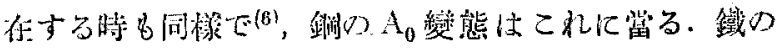

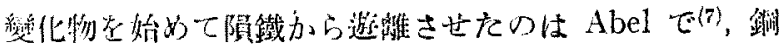

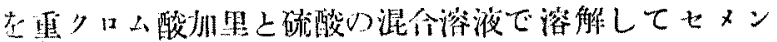

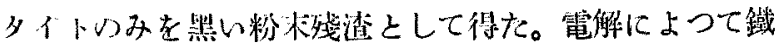

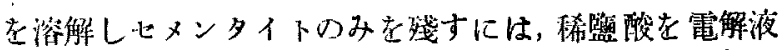

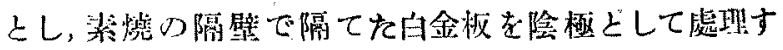

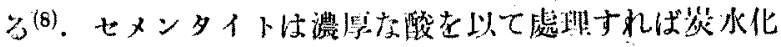

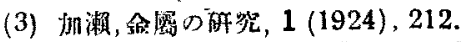

(4) Is. Weinschenk, Ann. Museum Wien, 4 (1889), 94

(5) 本多，村上，果北渧大理科数齿，6 (1917)，23.

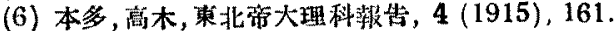

(7) F. A. Abcl, Proc, Inst, Mech, Eng., 33(1885), 30.

(8) J, Ó. Arnold, Reads, Proc. Inst, Mech, Eng., 82(1914), 223 . 


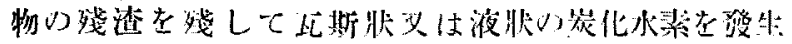
する。

ヒメンタイトの結品格子は Westgren, Phragmén, Wever，Polanyi，志村博士鉸 ${ }^{(9)}$ によってX線分析方法 を用ひて決定せられてるる。志村博士は低珪㨞スエーデ

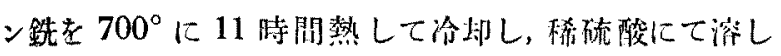

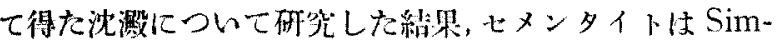
ple orthorhombic lattice $\Gamma_{0}$ に屬し, space group $V_{h}{ }^{16}$ で、格子管数は

$$
a=4.51_{3} \AA \quad b=5 \cdot 04_{8} \AA \quad c=6 \cdot 74 \AA
$$

であつて, Unit cell 円には $\mathrm{Fe}_{3} \mathrm{C} 4$ 分了在含むとし，原 子配置者多沈定した。年の後Westgren は更に精密な 测定をして，格子常數乞の他を次の如く沈定した。 ${ }^{(10)}$

趴方，格子常数は

$$
\begin{aligned}
& a=4.517 \AA \quad b=5.079 \AA \quad c=6.730 \AA \\
& \text { space group は同しく }{ }^{16} \\
& \text { 鐵及で炭素原了の情標は， }
\end{aligned}
$$

$$
\text { 8Fe : } \begin{aligned}
x, y, z ; & \bar{x}, \bar{y}, z+1,2 ; \bar{x}+1 / 2, y+1 / 2, \\
& \bar{z}+1 / 2 ; x+1 / 2, \bar{y}+1 / 2, \bar{z} ; \\
\bar{x}, \bar{y}, \bar{z} ; \quad & x, y, \bar{z}+1 / 2 ; x+1 / 2, \bar{y}+1 / 2, \\
& z+1 / 2 ; \bar{x}+1 / 2, y+1 / 2, z,
\end{aligned}
$$

$4 \mathrm{Fe}: u, v^{\prime}, 1 / 4 ; \bar{u}, \bar{v}, 3 / 4 ; \quad \bar{u}+1 / 2, z^{i}+1 / 2,1 / 4:$ $u+1 / 2, \bar{\imath}+1 / 2,3 / 4$

$4 \mathrm{C}: \quad u_{1}, v_{1}, 1 / 4 ; \quad \bar{u}_{1}, \bar{v}_{1}, 3 / 4 ; \quad \bar{u}_{1}+1 / 2, v_{1}+1 / 2$, $1 / 4 ; \quad u_{1}+1 / 2, \bar{v}_{1}+1 / 2,3 / 4$

但ᄂ $x=0.333, \quad y=0 \cdot 175, \quad z=0.065$,

$$
u=-0 \cdot 167, \quad i=0 \cdot 04 \text {, }
$$$$
u_{1}=0 \cdot 43, \quad i_{1}=-0 \cdot 13,
$$

鐵の炭化物に，七メンタイト以外の必のがあるが゙う

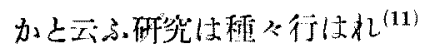

$\mathrm{Fe}_{3} \mathrm{C}, \mathrm{Fe}_{2} \mathrm{C}, \mathrm{FeC}_{2}, \mathrm{FeC}, \mathrm{Fe}_{4} \mathrm{C}, \mathrm{Fe}_{3} \mathrm{C}_{2}, \mathrm{Fe}_{5} \mathrm{C}$,

$\mathrm{Fe}_{12} \mathrm{C}$

の化學式が提出せられたてとがある。

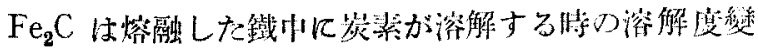

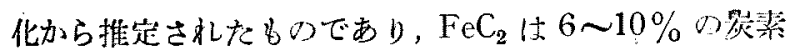

(9) A. Westgren, J. Ir. St. Inst., 103 (1921), 303; A. Westgren, Lindt, Z. Phys. Chem., 98 (1921), 181; A. Westgren, G. Phragmén, J. Ir. St. Inst., 105 (1922), 241; F. Wever, Mitt. K.-W.-I. Eisenforsch., 3 (1921), 45; ditto. 4 (1922), 67 ; S. B. Hendricks, Z. Krist, 74 (1930), 534 ; E. C. Bain, Chem. Met. Eng., 2(1921), 657; S.Schinura, J.Fac. Eng. Tolkyo. Imp. Univ., 20 (1931); 志村, 珷と铜，18 (1932)，583；S.B. Hèndricks, Z. Trist., 74 (1930), 534.

(10) A. Westgren, Avtryckur Jernkontorets Annaler für Ar, (1932), 457.

(11) F. D. Campbell, M.B. Kennedy, J.Iron \& Steel Inst., 62 (1902), 288 ; S. Hilpert. T. Dieckmann, Ber, clent. Chem. Ges, 48 (1915), 1281.

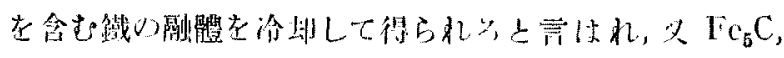

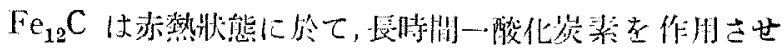
れげ出來ると言ふ.

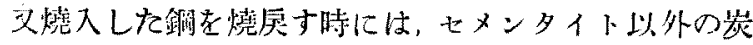
化物が生成されうであらうといふ豫想の下に，整々の溫

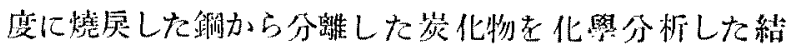

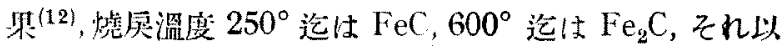

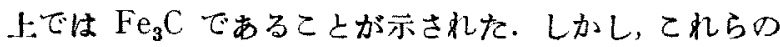
磁氣變態點けすべてセメンタイトのそ礼と一政し，叉X

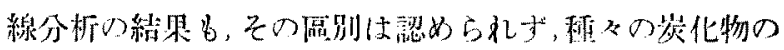
份在は疑问視せられてるるる。

\section{(2) 共析變態機構}

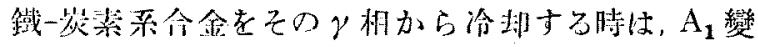

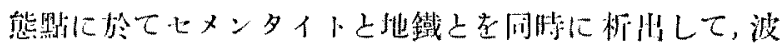

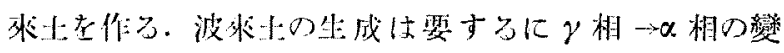
化々 $\gamma$ 相よりセメンタイトの析计との合成である。

$\gamma$ 相或は大洲川 (Austenite) は陑心す少恪了で $\alpha$ 相 或は地鐵は體心方方桥了一である。

この面心シ方格子より體心立方格了への變化は早くよ

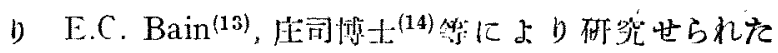
が, G. Kurjumow \& G. Sachs ${ }^{(15)}$ ， $1.4 \%$ C 銅を揢融

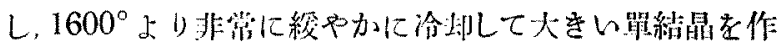

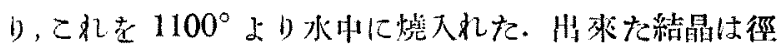
$10 \mathrm{~mm}$ ，長さ $70 \mathrm{~mm}$ 程度のもので, この樹狀昆 (dendrite)

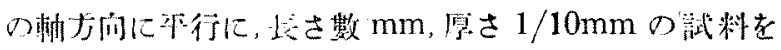
取り，乙㣗に上ってX線分析在行ひ， $\gamma$ 相の (111) 面上

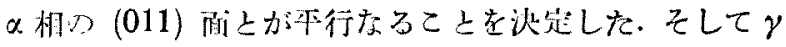
相から $\alpha$ 相への變化は $\gamma$ 相の (111) 面が [211]の方向 に移動し，(211) 面が [101] の力向に移動し，原子間隔の

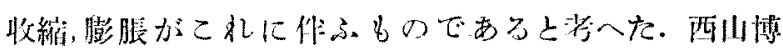

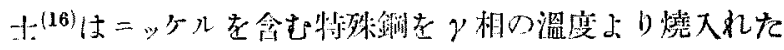

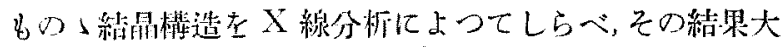
洲的は面心立少晶で, $\alpha$-旅留州 ( $\alpha$-Martensite) は體心

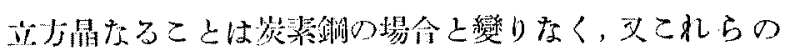

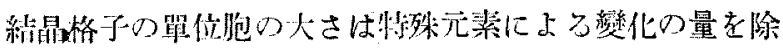

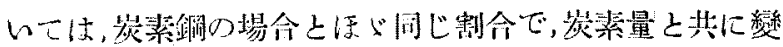

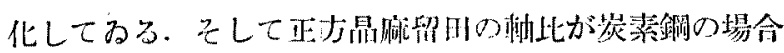

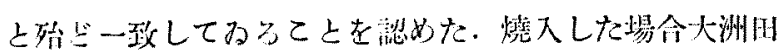

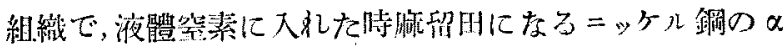

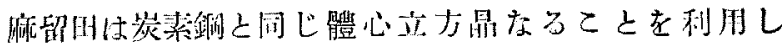

(12) F. Wever, G. Naeser, Mitt. I.-W.-I, Eisenforsch., 16 (1934),201.

(13) E. C. Bain, Trans, Amer. Inst, Min. Met. Tng,, 70 (1924), 25

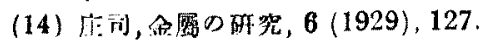

(15) G. Kurjumow, G. Sachs, Z. Phys., 64 (1936), 325

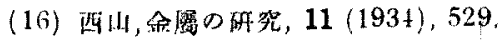




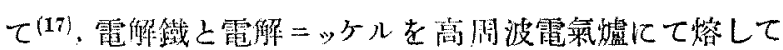
得た ニッケル鲖 $(\mathrm{Ni}=29.90 \%)$ を聺融照值下に 5 時問

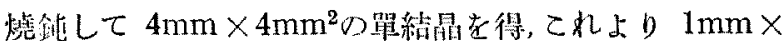

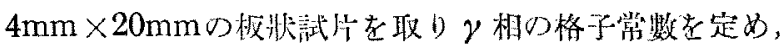
次にこれ液娟空素に 30 分闸浸して後再びX線分析

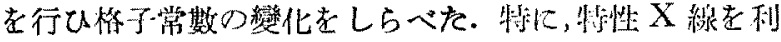
用した振動竄真 (ascillation photograph) による研究か ら Kurdjumow \& Sachs の (211) 面に於ける [101] 方向の妾りの代りに (111) 而に於けっ [211]方向人の 收縮考考八, $\gamma \rightarrow \alpha$ 變熊は，

$$
\begin{aligned}
& \gamma(111) / / \alpha(011) \\
& \gamma[\overline{2} 11] / / \alpha[01 \overline{1}]
\end{aligned}
$$

$$
\text { 郎古 } \gamma(01 \overline{1}) / / \alpha(100)
$$

と考人る方が筫驗とよく一致することを示した.毁ち $\gamma$ (111) shearing plane として $\gamma[\overline{211}]$ 方向に $19^{\circ} 28^{\prime}$ をけ simple shearをなしってれと同時に $\gamma[01 \overline{1}]$ のう 向に 13.3\% の膨脹, $\gamma[\overline{2} 11]$ 为向に $7.5 \%$ の收縮, こ れらと䑶直の力向に $1.9 \%$ の收街をなしていに變化す

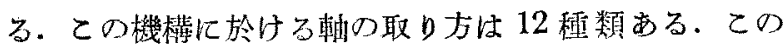
12 程類によつて生ずる $\alpha$ 相の軸の力向は冷却條件從つ て試驗片の外形に關係がある核である.川村工學士 ${ }^{(18)}$ はこの機棒によつて面心立方品より體心立方晶入變化す る場合の體積變化を計算し，變態前後の比較體積及び格 子常數をそれぞれ $v_{1}, v_{2}$ 及び $a ， a^{\prime}$ とすれば。

$$
v_{1}: v_{2}=a^{3}: 2 a^{3}=\frac{a^{3}}{2}: a^{3}
$$

\section{となるととを示した。}

$\gamma$ 相よりセメンタイトを析出する機㯇については，遠 藤博士 ${ }^{(19)}$ が Westgren の得た七メンタイトの絬品構造 を脚，立方晶の酸化戴が，六方晶の硫化鐵に警化する際 の變撸機模加ら颣推して次の如く結論した，即ち，炭素 を固溶してるる $\gamma$ 相よりセメンタイトを析出する場合 には，その炭素原子は鐵の面心立方格子に於て，その最当 閠い間隐郎ち體心及び體心と同價佔の位置に當る體心を 通つた [110] と稜 $[001]$ との交點に順次に入り，第 1 圖 の如く存る.乙の場合 $\gamma$ [001] の方向に $24.9 \%$ 膨脹し， $\gamma$ [110] の力向に $0.4 \%$ 收縮する \& (120) を过りの面として [001] 力向に $19^{\circ}$ ，同時に $\gamma(1 \overline{1} 3)$ 面を汇りの面として [110]の方向に $12^{\circ} 12^{\prime}$ の过りをな

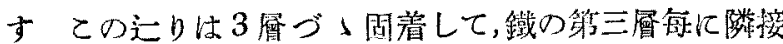

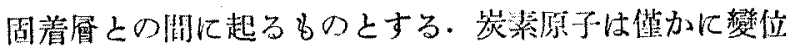
して宽定し，更に [110]の方に全骴として $2 \%$ 收縮し， 次いでこの方向に $102 \%$ 收縮し，同時に交互に各窟が

(17) 西山, 金成の研究, 11 (1934), 561.

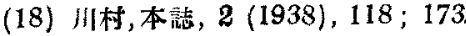

(19) 望蘶, 本誌 $3(1939), 201$.
[110] 万向に 3/20 迄れば，セメンタイトの結晶格子と 极。.

$$
\text { 影部 } \begin{aligned}
& \mathrm{Fe}_{3} \mathrm{C}(001) / / \gamma(1 \mathrm{~T} 0) \\
& \mathrm{Fe}_{3} \mathrm{C}[100] / / \gamma[001]
\end{aligned}
$$

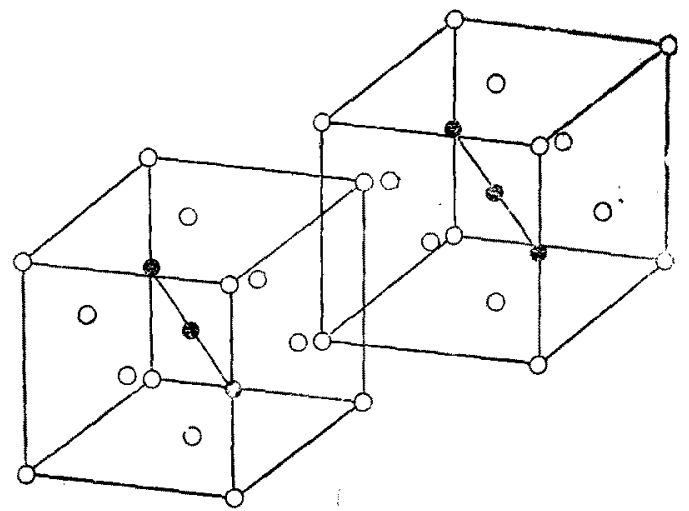

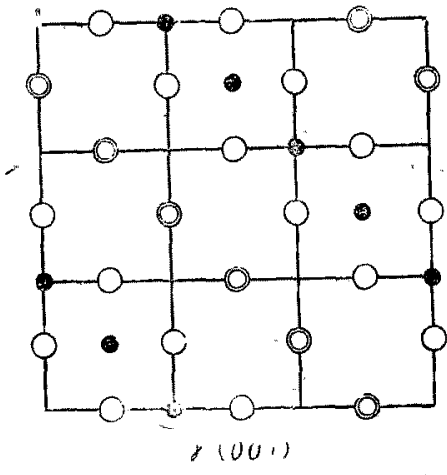

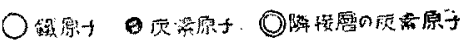

第 1 圆
となる。そして共 析變態儿於て現 れるセメンタイト の薄板狀結晶の廣 レ面はセメンタイ トの(001)面で,短 い軸は [001] であ 3. (20)

合金が共晶し或 快共析變態をする 場合，その兩成分 のどちらが先に晶

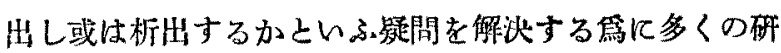

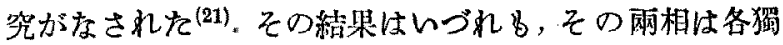
立に同時に生ずるてとを示してるる。岩瀨博士 ${ }^{(22)}$ は

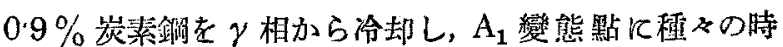

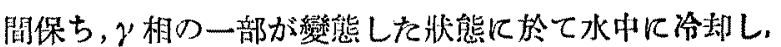
波來上の巾と長さとの關係をしらべて，波来土に於ては 地鐵と七ヌンタイトとが同時に獨立に生成するbのとし そ. Carpenter \& Robertson ${ }^{(23)}$ は $\gamma$ 相から波來土の生

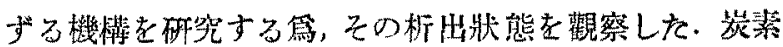

(20) 志村,東亭帝大工學部紀要, 20 (1931)，1

(21) R. Vogel, Z. anorg. Chem., 76 (1912), 425 ; Rosenhain, Tucker, Phil. Trans. Roy, Soc., 1 (1909), 209; C. Benedicks, Inst. Z, fur Met., 1 (1911), 184 ; L. Brady, J. Inst. Met., 2 (1922), 369; W. Guertler, Metallographie, 1 (1912), 249; R. Vogel, Z. anorg. Chem., 116 (1921)，21；演住，金屬の研觉，2(1925)， 405.

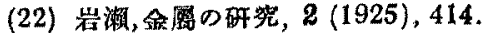

(23) H. C. H. Carpenter, J. M. Roperțson, J. Iron \& Steel Inst., 125 (1932), 302, 
鋼の棒を $1050^{\circ}$ に一樣に加熱して後,その棒の一咱を變 態點以下に冷却し，他の一端は元の溫度に保ち，或つ㭙間

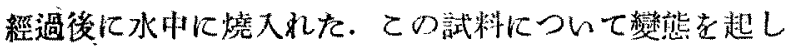

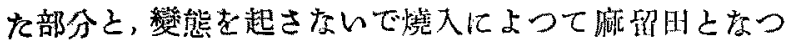

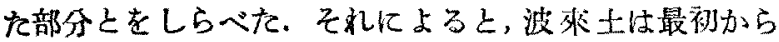
對になつた平行した匴㸛のものが出現するのではなく， 結晶粒界（過共析銅或は亞共析銅に於ては，結昆粒界儿 析出してわる初析のセメンタイト戴は地鐵に接した慜) に於て變態が始まり，それが次第に $\gamma$ 相結晶の內部に及 んで行くこと第2 圆の如くなつてわる.冷却が僬いる 居仕第 2 圆a の如く居の面儿垂直 の方向一發達して行き, 冷却が制 合に早い上 $\mathrm{b}$ 圆の如く變態の開始 點加ら故射临に發達して行く.こ の様にして $\alpha$ 相とセメンタイトと は同時に形成され，その一對は同 時俘達して行く一稼な $\gamma$ 相に 於ては波來土が數點，郎ちいくつ

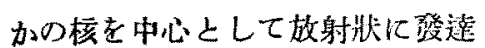
することがあり，顯微鏡下では閂 形に見えろ. H. Hanemann u. O. Schröder ${ }^{(24)}$ はヂェラルミン等で は細い析出が徐々に起る一方, 㣀

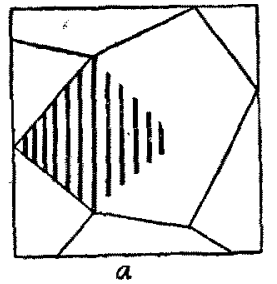
鍮の $\beta$ 相加ら析出する $\alpha$ 相队，亞第 2 圆 波来土の生成 共析成分の銓老適當に處理する時 に析出する $\alpha$ 鐵は速汃に大をな結

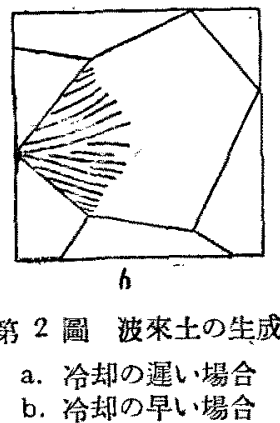
晶となることに着目して，Glöker の分類になる第一程 固溶體（原子の置換に上る固溶體）と第二種固溶體（溶 質原子が恪子間㭞に入り込んでるる固溶體）とでは，析 出の際に起る原子の摭散の仕方が巽り，前者では隣り合

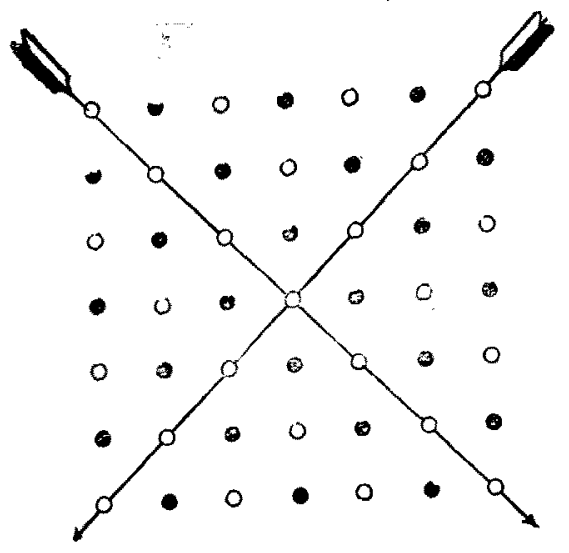

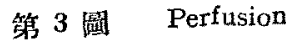

つた原子加赫 所を交換する て上ようて溶 筫原子が移 動し，後者で 第3圖の如 〈矢印O力问 に溶貿原子が 列を作つて格 子閒隐老移勤 なると考へ, こ邓椂な原子 移動の方法を “Perfusion”之名付けた. Perfusionを 起すには，その格子內に Perfusion の方向老持つ桹に溶

(24) H. Hanemann, O. Schröder, Z. Metallk., 23 (1931), $172 ; 297$.
筫原丁が存在してわるてとが必捱である。

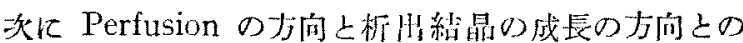

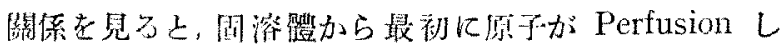
て出て行つた所，㕛は Perfusion して集つて桃を所に，

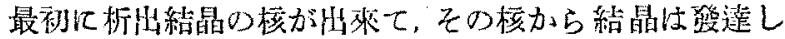
て行く第 4 圆に於て，内側の圆を核の裴面とし，外側の

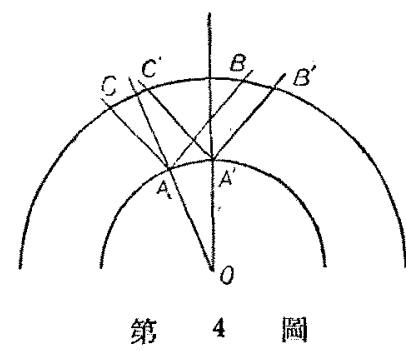

圈考固溶體に於ける溶質 のーDの管濃度面と才れ ば, Perfusion の才尚が $\mathrm{AC}, \mathrm{AB}$ の方向である場 合には，AB+ACが極 小の所で菬度应速かに一。 樣になららとするから， 結晶の成長は乙の場所て 最も速加に行はれる。即ち，核の中心を通り Perfusion の方向のなす角の 2 等分線の方向に結晶は最も速か儿成 長する。乙机は Perfusion の方向が二つ以上ある場合 む同椎である. H. Hanemann u. O. Schröder ${ }^{(24)}$ は

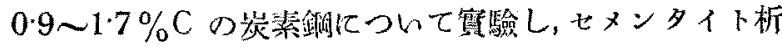
出の場合には，岑素原子の Perfusionする方向は $\gamma$ 結 晶格子に於ては第 5 圖の如く，體心と各稜の中點とを絬

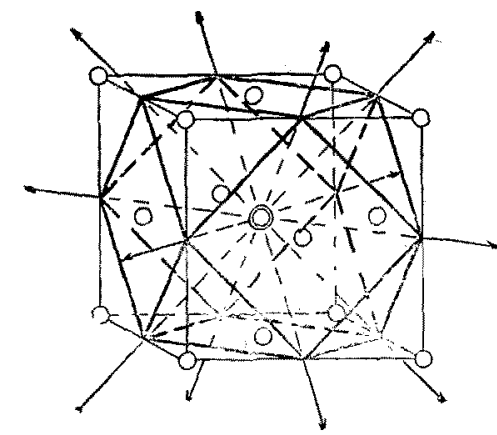

第 5 圆 んな゙線となること

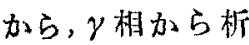
出するセメンタイ トの面估当之の立 方體の面 $\gamma(100)$ か文は八面跓の面 $\gamma(111)$ に平行で あるとした。この 機權によれば析计 物の面は、もとの 固溶體の結昌㯢造 のみに關倸することになるが、R.F.Mehl 及びその其

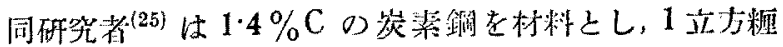

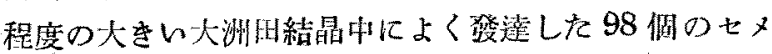
ンタイト板の方南を stereographic projection にとつ て、それらが三つの圆周に群つて現はれてわるとと智 ote.

この圓の一つの中心が projection の中心となる稼に

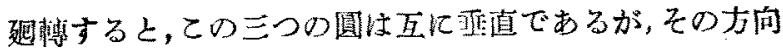

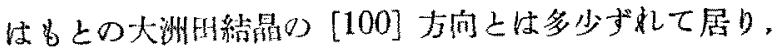

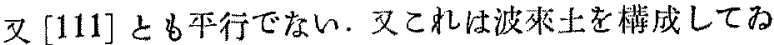

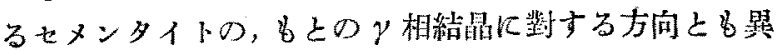
ることは碓かである。その他幾多の事例を舉げて，固溶

(25) R. F, Mehl C. S. Barett, W. Smith, Nature, 129 (1932), 313. 


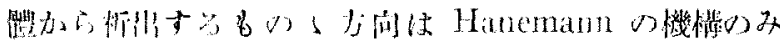

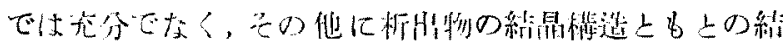

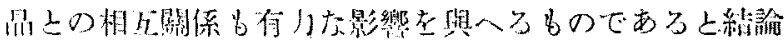
してるっ.

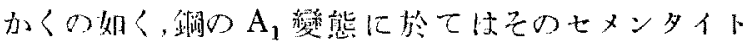

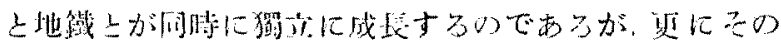

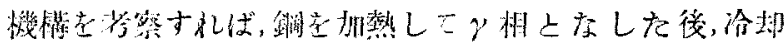

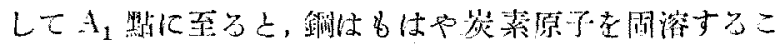

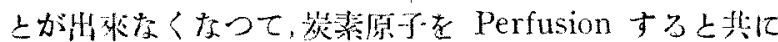

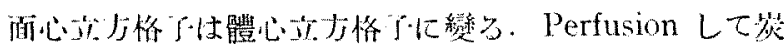

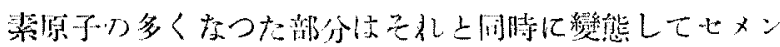

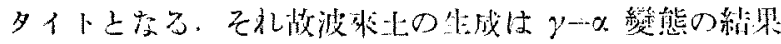

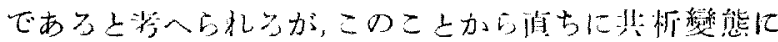

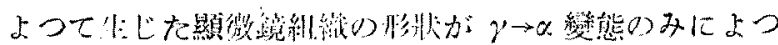

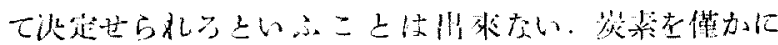

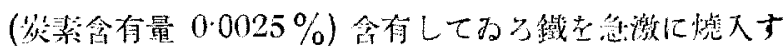

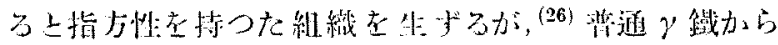

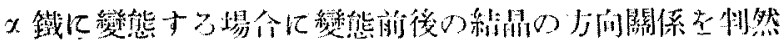

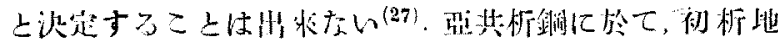

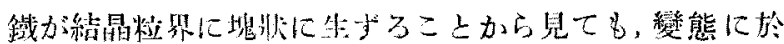

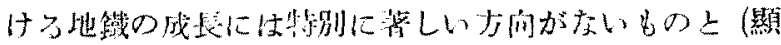

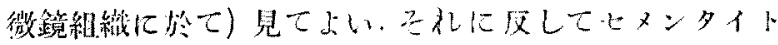

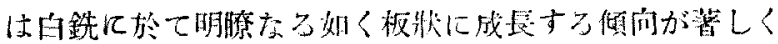

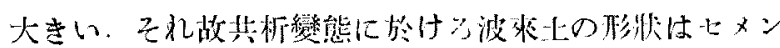
タイトによつて決过されつ为の上見てよい。

\section{（3）共析變態に於ける球狀セメンタイトの析出}

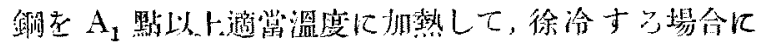

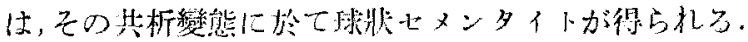

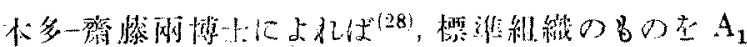

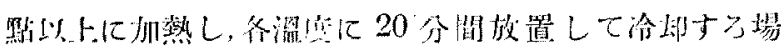

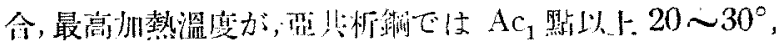

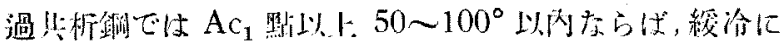

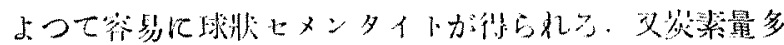
き場命には和析七メンタイトが球将化し，嵒入によつて

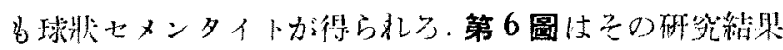

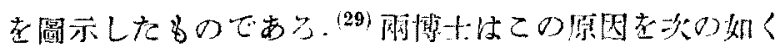
福明した。

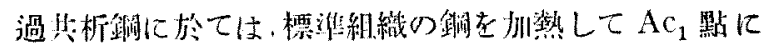

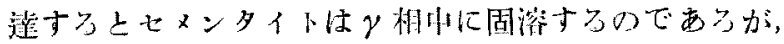

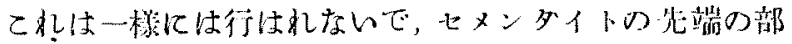

(26) A. Sauveur, C. H. Chou, Trans, Amer. Min. Met. Eng., 84 (1929), 350 .

(27) O. H. Desch. Text-Bools of Physical Chemistry, (1939).

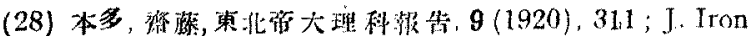
Steel Inst. $102(1920), 261$

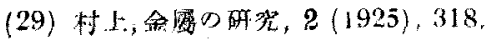

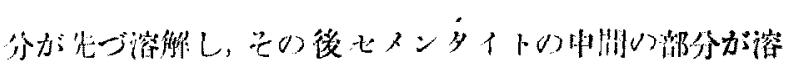

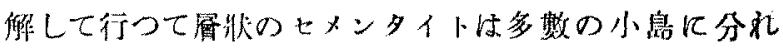

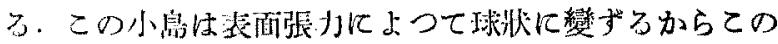
溫度から䍡入したものは球狀七メンタイト支殘存して居

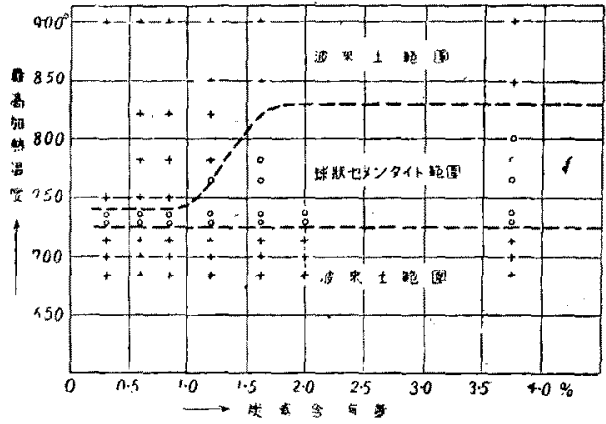

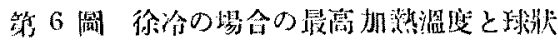
波來上击成との關係
ろのである。 この温度か ら徐冾して b膡状七” ンタイト なら布以理 州生, $\gamma$ 相 に七メンタ イトが溶解

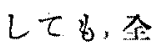
部が一椾应

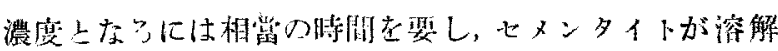

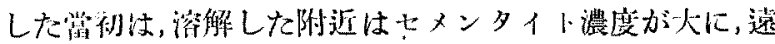

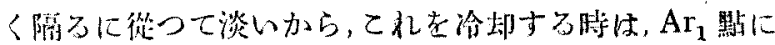
西つて過能和になつたセメンタイトは殘つてわる球胀七

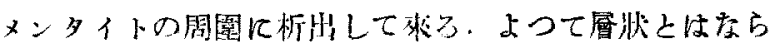

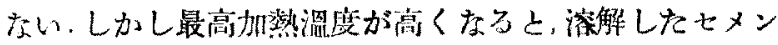

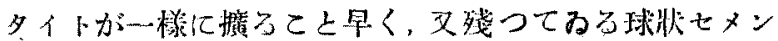
タイトb然く存つから，冷却して $A_{1}$ 點に達した時，七

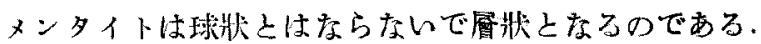

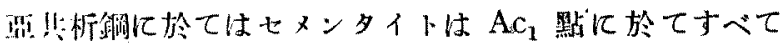
間溶してしまる.から，ての試料老冷却して來ると $\mathrm{Ar}_{1}$ 點 に於て波爽土之なるのである：

久 J.H. Whitely ${ }^{(30)}$ はこの球狀七ヌンタイト生成を

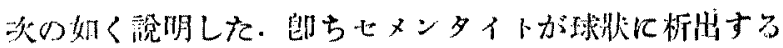
のは; 其析變態索起寸前に毁にヒメンタイトの核が存在 して居るからである・元棑波來上は $\gamma$ 相を冷期して行つ て $\mathrm{Ar}_{1}$ 點以下少しく過冷却をした拲に生じたものであ つて，七メンタイトの核が、たと一顯微鏡では濯められんな ん程に小さんものであつてもそれが保有す机ば， $\mathrm{Ar}_{1}$ 點

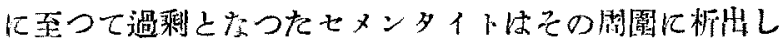

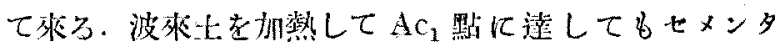
イトは全部 $\gamma$ 相へ溶解してしまふものでなく，七メンタ イトがその核までもなくなつてしまふには $\mathrm{Ac}_{1}$ 點より も遥かに高く过加熱しなければならない.それ故 $\mathrm{Ac}_{1}$ 點

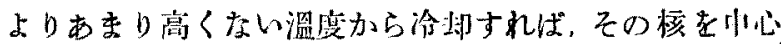

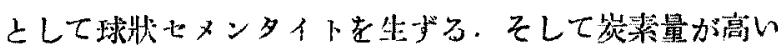
程，過其析鏋に於てはセメンタイトの核が消失し難いに

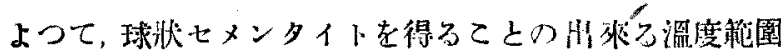
はより高くなるのである。

(30) J.H. Whitely, J. Iron \& Steel Inst., 105 (1922), 339; 97 (1918), 353 . 
叉 P. Payson, W. L. Hodapp \& J. Leader ${ }^{(31)}$ は轱

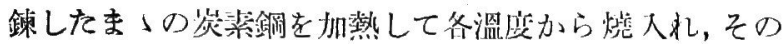
燒入組成に於て波來上の認められない最低溫度（これを 彼等は minumum austenizing temperature と称した.) を求め,その溫度に 1 時間保持した後，變態點以下の各 溫度に於て isothermal transformation 在行はせ，球狀

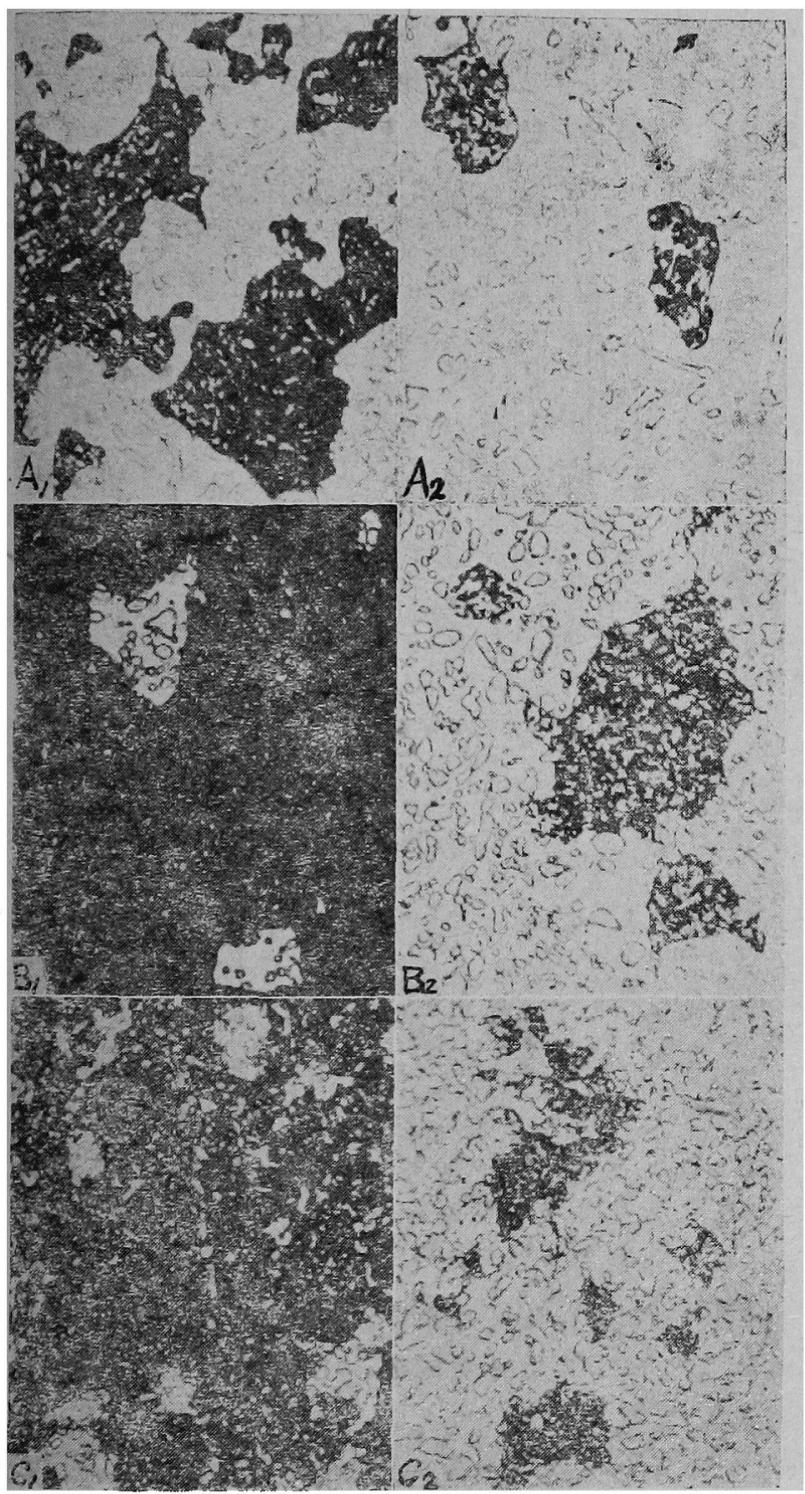

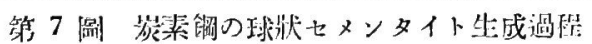

\begin{tabular}{|c|c|}
\hline & \\
\hline & $46 \% \mathrm{C}$ 怕溫變態下記 \\
\hline & 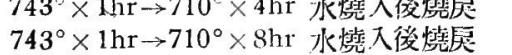 \\
\hline & 恒溫變热下記 \\
\hline & $749^{\circ} \times 1 \mathrm{hr} \rightarrow 724^{\circ} \times 25 \mathrm{hr}$ 水燒大後然㞔 \\
\hline & $749^{\circ} \times 1 \mathrm{hr} \rightarrow 724^{\circ} \times 4 \mathrm{hr}$ 水垒入後燒㕄 \\
\hline & $\begin{array}{l}1.16 \% \mathrm{C} \text { 怕盕戀態狺記 } \\
760^{\circ} \times 1 \mathrm{hr} \rightarrow 7221^{\circ} \times 3 \mathrm{~min}\end{array}$ \\
\hline & $760^{\circ} \times 1 \mathrm{hr} \rightarrow 721^{\circ} \times$ \\
\hline
\end{tabular}

(31) P. Payson, W. L. Hodapp, J.Leader, Trans. Amer. Soc. Metals, $28(\mathbf{1 9 4 0 )}, 306$.

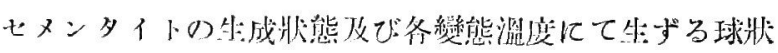

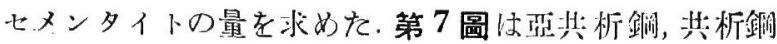
及び過其析鎆に於ける球状七メンタイトの生成過程を示 す顯微籍組織であり，茅 1 表は各變態溫度に於て生ずる

第 1 坛 恒溫變態によつて坐成する層狀波來土の量

\begin{tabular}{|c|c|c|c|c|c|c|c|c|c|}
\hline \multirow{2}{*}{\multicolumn{2}{|c|}{ 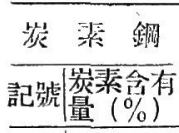 }} & \multirow{2}{*}{ 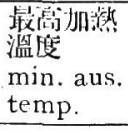 } & \multicolumn{7}{|c|}{ 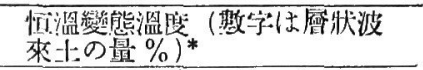 } \\
\hline & & & $735^{c}$ & $732^{c}$ & $727^{\circ}$ & $721^{\mathrm{c}}$ & $716^{\mathrm{c}}$ & $710^{\circ}$ & $704^{\circ}$ \\
\hline A & 33. & $754^{\circ}$ & - & 15 & 75 & 90 & - & - & - \\
\hline B & 0 & 74 & - & - & - & - & - & 10 & \\
\hline C & & 74 & - & - & 40 & - & 90 & - & 100 \\
\hline I) & & 74 & - & - & tr. & 15 & 30 & - & 40 \\
\hline $\mathrm{E}$ & $1 \cdot 16$ & $760^{\circ}$ & - & - & - & - & tr. & tr. & 5 \\
\hline
\end{tabular}

(*變態特䦌の記錄なし)

波水上の最を示寸ものである。この綃果によれば其析變

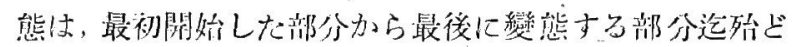
同じ大さの球状セメンタイトを少成して行くことがかか

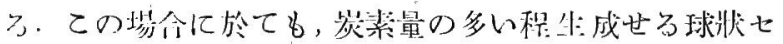
メンタイトの多いてとは明らかである。

七メンタイトの析出及び闻溶現象の機模の詳紐は，前 䬣にも速べた如く来だ我々には，完全には明膫でないが， この現象は, 絬晶體がその溶液から析州し，又溶解して溶

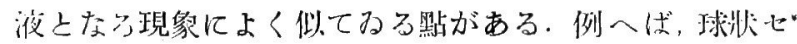
メンタイトを加熱して行けばその微小な粘了は，その喪

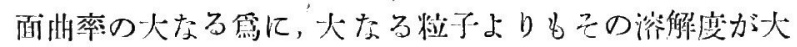

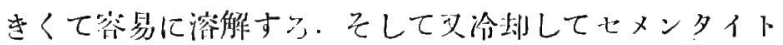

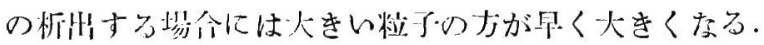
Osmond ${ }^{(\mathbf{3 2})}$ や Ishewsky ${ }^{(\mathbf{3 3})}$ はこ狄が食阷水から火きい

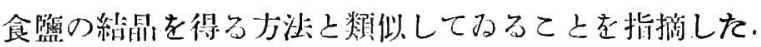
それ故，鍓をこの變態點の、トに反覆加熱すれば小さ

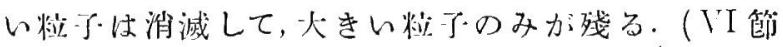
參!!得).

納長く析州したセメンタイトは高溫度に長時閒加熱す

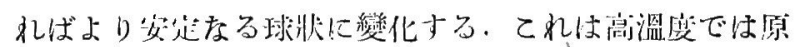

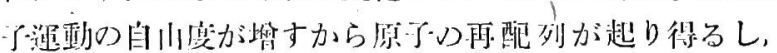
为實際に起う，そして物理的に一層安定灰状態上なる。 この現象は液體に於て, 裴酒張机よつて起される現象

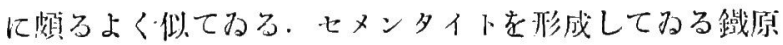

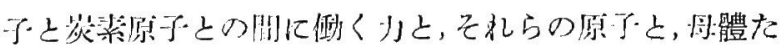
๖ $\gamma$ 相又は $\alpha$ 相を形成してるる鐵原子との間に価く力

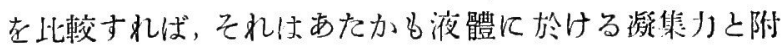
着力との關係にあ门，七メンタイトの球状化を，その不質 们な機棈には觸扎得ないとしても，裴面張力によつて說 明することは理解老钓曻ならしめる。

$(つ 5 n<)$

(33) Ishewsky, Metallurgia, 8 (1911), 182. 